\title{
Pengaruh Pemberian Media Booklet Kesehatan Reproduksi terkait Cybersex (Studi di SMA Kabupaten Banyuwangi)
}

\author{
Rizky Dwiyanti Yunita ${ }^{1}$, Sri Achadi Nugraheni ${ }^{2}$, Siti Fatimah Pradigdo ${ }^{2}$ \\ ${ }^{1}$ Magister Ilmu Kesehatan Masyarakat Universitas Diponegoro \\ ${ }^{2}$ Staf Pengajar Program Magister Ilmu Kesehatan Masyarakat Universitas Diponegoro \\ *Corresponding author : rizkydwiyanti8@gmail.com
}

Info Artikel : Diterima 05 April 2019 ; Disetujui 06 Januari 2020 ; Publikasi 01 Februari 2020

\begin{abstract}
ABSTRAK
Latar belakang: Materi seksual online yang semakin mudah untuk diakses dibandingkan dunia nyata membuat remaja menjadi konsumen setia cybersex. Penelitian di Jawa Timur menunjukkan hasil 76,8\% penikmat cybersex ada pada usia 15 - 17 tahun. Tujuan penelitian untuk mengetahui pengaruh pemberian pendidikan kesehatan reproduksi terhadap pengetahuan, persepsi dan praktik remaja terkait cybersex.

Metode: Jenis penelitian adalah Quasi Eksperimental dengan metode Pretest - Posttest Control Group Design terhadap 66 siswa. Sampel dipilih dengan teknik Purposive Sampling, dengan jumlah 33 kelompok intervensi dan 33 kelompok kontrol. pemilihan sampel dibantu oleh guru BK, sebelum pemberian materi oleh guru BK diadakan pre test dan pada kelompok intervensi diberikan booklet, setelah pemberian intervensi dilakukan post test. Metode pengumpulan data dengan menggunakan kuesioner terstruktur.

Hasil: Hasil penelitian menunjukkan tidak ada perbedaan pengetahuan, persepsi praktik dan variabel penganggu lainnya sebelum pemberian pendidikan kesehatan reproduksi antara kelompok intervensi dan kelompok kontrol ( $p>0.05)$, ada perbedaan pengetahuan, persepsi praktik dan variabel penganggu lainnya sesudah pemberian pendidikan kesehatan reproduksi antara kelompok intervensi dan kelompok kontrol $(\mathrm{p}<0.05)$, ada perbedaan pengetahuan, persepsi dan praktik remaja terkait cybersex sebelum dan setelah pemberian pendidikan kesehatan reproduksi $(\mathrm{p}<0.05)$, tidak ada perbedaan perubahan pengetahuan, persepsi dan praktik remaja terkait cybersex sebelum dan setelah pemberian pendidikan kesehatan reproduksi pada kelompok intervensi dan kelompok kontrol ( $\mathrm{p}>0.05)$.

Simpulan: Peran keluarga dan guru sangat dibutuhkan untuk menanggulangi berkembangnya aktivitas berselancar di media cybersex, melalui pendekatan dan penyuluhan kesehatan secara continue diharapkan dapat menurunkan angka kejadian kasus HIV, KTD dan aborsi.
\end{abstract}

Kata kunci: Booklet, Kesehatan Reproduksi, Cybersex.

\section{ABSTRACT}

Title: Influence of Booklet to Reproductive Health related to Cybersex (Study in Banyuwangi Regency High School)

Background: Online sexual material are easier to reach compared to offline material which makes adolescent became a loyal consumen of cybersex. Research in East Java showed that $76.8 \%$ cybersex users are 15 - 17 years old. The aim of this study was to describe the effect of reproductive health education to knowledge, perception, and practice of adolescents related to cybersex matters.

Method: This was a quasi experimental using pre test-post test control group design to 66 students. Samples were chosen using purposive sampling technique. There were 33 samples of case group and 33 samples of control group. Counseling teachers were helping through the process of choosing samples. The intervention was conducted by giving a booklet to the case group. Data collected using structured questionaire.

Result: Result showed that there was no differences in knowledge, perception, practice, and confounding variables before intervention between case group and control group ( $p>0.05)$. There was a differences between 
knowledge, perception, practice, and confounding variables after intervention between case group and control group $(p<0.05)$. There was a differences between knowledge, perception, practice, and confounding variables before and after intervention between case group and control group $(p<0.05)$. There was no differences between knowledge, perception, and practice related to cybersex before and after reproductive health education to case group and control group ( $p>0.05)$.

Conclusion: Family's and teacher's role are necessary to prevent the activity of surfing cybersex online. By conducting an approach and socialization about reproductive health continuosly, it is hoped that it might decrease the number of unwanted pregnancy, abortion and HIV.

Keywords: Booklet, Reproductive Health, Cybersex

\section{PENDAHULUAN}

Aktivitas cybersex tumbuh cukup pesat, terutama di kota - kota besar dimana internet semakin mudah diakses. Menurut data survey kementrian informasi dan komunikasi, peringkat pengakses situs porno di indonesia pada tahun 2013 indonesia menduduki peringkat ke-enam pengakses situs porno, tahun 2014 meningkat menjadi peringkat ke-tiga, dan tahun 2015 menjadi peringkat ke-dua. Menurut ketua hotline pendidikan Surabaya, Isa Anshori, kasus seksual yang melibatkan anak usia sekolah terus mengalami peningkatan dari tahun ke tahun. Jumlah kasus meningkat 50\% dari tahun 2014 ke 2015. Dari jumlah itu $10 \%$ kasus terjadi disekolah. ${ }^{1}$

Permasalahan kesehatan reproduksi pada remaja paling tinggi ada pada kasus HIV/AIDS, berdasarkan laporan propinsi di jawa timur dalam kementrian kesehatan RI jenderal pengendalian penyakit dan penyehatan lingkungan, dengan jumlah kumulatif infeksi HIV yang dilaporkan sejak 1987 sampai dengan september 2014 Jawa Timur masuk dalam urutan ke dua dengan jumlah 19.249 kasus dengan pembagian wilayah Surabaya, Malang 3.462 dan Banyuwangi 2.489 kasus. $^{2}$ Di Kabupaten Banyuwangi tercatat sampai bulan september 2015 penderita HIV mencapai 2374 kasus, sedangkan AIDS 1126 kasus dan total kematian orang dengan HIV/AIDS (ODHA) mencapai 339 kematian). ${ }^{3}$

Remaja merupakan masa perkembangan dimana keingintahuan tentang seks juga meningkat, remaja selalu berusaha mencari lebih banyak informasi mengenai seks, hanya sedikit remaja yang berharap mendapatkan seluk beluk tentang seks dapat dipelajari dari orang tuanya. Oleh karena itu remaja mencari berbagai sumber informasi yang mungkin dapat diperoleh, misalnya karena higiene seks sekolah atau perguruan tinggi, membahas dengan teman- teman, buku-buku tentang seks, atau mengadakan percobaan dengan jalan masturbasi, bercumbu, atau bersenggama. ${ }^{4}$ Pada masa ini remaja mengalami perkembangan penting yaitu kognitif, emosi, sosial dan seksual. Kurangnya pemahaman tentang seksual. Perkembangan ini mulai dari usia 12 hingga 20 tahun, kurangnya pemahaman ini disebabkan oleh berbagai faktor antara lain: adat istiadat, budaya, agama, dan kurangnya pemahaman dari sumber yang benar.
Kurangnya pemahaman ini mengakibatkan berbagai dampak yang justru amat merugikan kelompok remaja dan keluarganya. ${ }^{5}$

Cybersex merupakan aktivitas yang terjadi ketika orang menggunakan komputer yang berisi tentang teks, suara dan gambar yang didapatkan dari software atau internet untuk stimulus seksual dan secara khusus mencakup dua atau lebih orang berinterksi di internet yang membangkitkan gairah seksual satu dengan yang lainnya. ${ }^{6}$

Faktor-faktor yang mempengaruhi pendidikan kesehatan reproduksi remaja antara lain pengetahuan, persepsi, praktik, pengaruh teman sebaya, peran keluarga dan paparan media.

Pengetahuan merupakan segala sesuatu yang diketahui berkenaan dengan sesuatu hal. Kata kerjanya adalah berpengetahuan yang artinya mempunyai pengetahuan, mengerti sesudah melihat (menyaksikan, mengalami, dsb), kenal (akan), mengenal, mengindahkan, memedulikan, mengerti, berpengertian. pengetahuan adalah segala sesuatu yang diketahui, dimengerti, dikenal dan diperlukan oleh responden setelah selesainya kegiatan atau program. ${ }^{7}$

Persepsi merupakan mengenal dan memilih berbagai objek sehubungan dengan tindakan yang akan diambil. Persepsi adalah pengamatan tentang objek, peristiwa atau hubungan-hubungan yang diperoleh dengan menyimpulkan informasi dan menafsirkan pesan. ${ }^{8}$

Praktik merupakan seseorang yang telah mengetahui stimulus/ objek kesehatan, kemudian mengadakan penilaian atau pendapat terhadap apa yang diketahui, proses selanjutnya diharapkan ia akan melaksanakan/ mempraktikkan apa yang diketahui atau disikapinya (di nilai baik). Inilah yang disebut praktik (practice) kesehatan atau dapat dikatakan praktik kesehatan (overt behavior). Praktik yang dimaksudkan dalam penelitian ini adalah praktik remaja terkait cybersex, dimana remaja dalam era ini telah diberikan fasilitas dan kemudahan dalam mewujudkan apa yang mereka ingin ketahui. ${ }^{9}$

Peran keluarga merupakan Peran keluarga menggambarkan seperangkat perilaku interpersonal, sifat, kegiatan yang berhubungan dengan individu dalam posisi dan situasi tertentu. Peran individu dalam keluarga didasari oleh harapan dan pola perilaku dari keluarga, kelompok, peran merupakan 
serangkaian tingkah laku yang diarapkan orang lain terhadap seseorang sesuai dengan kedudukan dalam system, dimana dapat diperngaruhi keadaan sosial. ${ }^{10}$

Peran teman sebaya sebagai sumber informasi dan emosional merupakan salah satu sumber untuk pemecahan masalah dan perolehan pengetahuan, sehingga takaran informais yang diterima oleh remaja dapat mempengaruhi perubahan perilaku. Perilaku manusia dapat berubah akibat dari emosi seseorang, dengan emosi tersebut individu terangsang terhadap objek atau perubahan yang disadari sehingga kemungkinan remaja merubah sifat atau perilaku juga bisa terjadi. ${ }^{11}$

Internet berfungsi sebagai aspek komunikasi penyedia informasi, dan fasilitas promosi, internet dapat menghubungkan manusia dengan berbagai pihak diberbagai lokasi diseluruh dunia, sehingga Paparan media dapat diartikan segala sesuatu yang dapat diuraikan melalui media televisi, dapat memberikan informasi baik secara hiburan maupun pengetahuan.

Penelitian ini menggunakan media booklet kesehatan reproduksi pada remaja dan resiko mengakses situs cybersex, Booklet adalah suatu media untuk menyampaikan pesan-pesan kesehatan dalam bentuk tulisan dan gambar. Booklet sebagai saluran, alat bantu, sarana dan sumber daya pendukungnya untuk menyampaikan pesan harus menyesuaikan dengan isi materi yang akan disampaikan. $^{12}$

Tujuan dari penelitian ini adalah mengidentifikasi pengaruh pemberian booklet kesehatan reproduksi terhadap pengetahuan, persepsi dan praktik remaja terkait cybersex di SMA muhammadiyah Kabupaten Banyuwangi.

\section{MATERI DAN METODE}

Penelitian ini penelitian Quasy Eksperemint menggunakan design pre test - post test control group design. Penelitian dilaksanakan pada bulan Januari sampai dengan Februari tahun 2017 yang berlokasi di SMU Muhammadiyah 2 dan 3 Genteng Kabupaten Banyuwangi. Rentang waktu yang dibutuhkan antara pretest dan posttest yaitu 14 hari (2 minggu).

Populasi adalah remaja SMU Muhammadiyah 2 dan 3 Genteng yang dipilih berdasarkan kriteria inklusi dan eksklusi. Tehnik pengumpulan data dilakukan sekaligus pada satu kali kegiatan pengamatan. Tehnik pengambilan sampling menggunakan purposive sampling. Sejumlah 66 siswa (33 kelompok kontrol dan 33 kelompok intervensi). Instrumen penelitian menggunakan kuesioner. Penelitian dilakukan dengan melibatkan guru BK untuk memberikan pendidikan kesehatan reproduksi pada masing masing kelompok dan pada kelompok intervensi setelah diberikan pendidikan keseahtan reproduksi dibagikan booklet untuk dibawa pulang. Setelah terkumpul maka data dapat diolah dan ditabulasikan, kemudian akan dilakukan analisis data secara univariat dan bivariat, data diuji menggunakan Wilcoxon signed rank test dan Mann Whitney test karena data tidak berdistribusi normal. Uji normalitas data menggunakan Shapiro wilk. ${ }^{13}$

\section{HASIL DAN PEMBAHASAN}

Seluruh variabel diuji normalitas menggunakan Saphiro Wilk karena sampel kurang dari 50. Memiliki varian yang tidak sama dan tidak berdistribusi normal. Pendidikan kesehatan reproduksi merupakan salah satu upaya kesehatan institusi yang bertujuan untuk meningkatkan derajat kesehatan anak didik dan meningkatkan kualitas sumber daya manusia13.

Gambaran perbedaan pengetahuan, persepsi dan praktik remaja terkait cybersex, peran keluarga, taman sebaya dan paparan media sebelum diberikan pendidikan kesehatan reproduksi pada kelompok kontrol dan kelompok intervensi

Pada awal penelitian dilakukan penyebaran kuesioner sebelum pemberian pendidikan kesehatan reproduksi terhadap kelompok intervensi dan kelompok control

Gambar 1 : gambaran sebelum intervensi pada Kelompok Kontrol dan kelompok intervensi

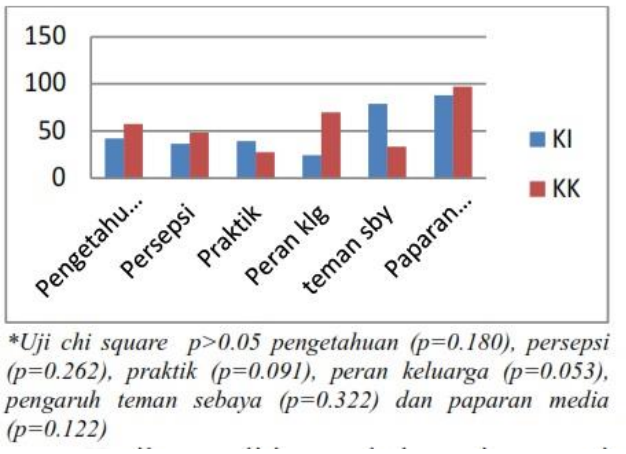

Hasil penelitian sebelum intervensi terhadap pengetahuan, persepi, praktik, peran keluarga, pengaruh teman sebaya dan paparan media sebelum diberikan intervensi baik pada kelompok intervensi dan kelompok kontrol didapatkan hasil p>0,05, hal ini menunjukkan bahwa tidak ada perbedaan yang bermakna terhadap pengetahuan, persepi, praktik, peran keluarga, pengaruh teman sebaya dan paparan media sebelum diberikan intervensi baik pada kelompok intervensi dan kelompok control. Hal ini dikarenakan kelompok intervensi dan kontrol belum mendapatkan pendidikan kesehatan reproduksi, namun pada kelompok kontrol dan intervensi mampu mencari informasi dari media massa, televisi, internet maupun pengalaman saat di kelas dan pergaulan dengan temannya.

Pengetahuan yang benar tentang seks akan mendorong remaja untuk berfikir tentang resiko yang akan mereka hadapi ketika remaja melakukan free sex. pengetahuan dipengaruhi oleh faktor internal yaitu pendidikan yang diperlukan untuk 
mendapatkan informasi misalnya hal-hal yang menunjang kesehatan sehingga meningkatkan kualitas hidup. ${ }^{14}$

Gambaran perbedaan pengetahuan, persepsi dan praktik remaja terkait cybersex, peran keluarga, teman sebaya dan paparan media sesudah diberikan pendidikan kesehatan reproduksi pada kelompok kontrol dan kelompok intervensi

Post Test diberikan sesudah kelompok intevrensi dan kelompok kontrol diberikan pendidikan kesehatan reproduksi

Gambar 2 : gambaran sesudah intervensi pada Kelompok Kontrol dan kelompok intervensi

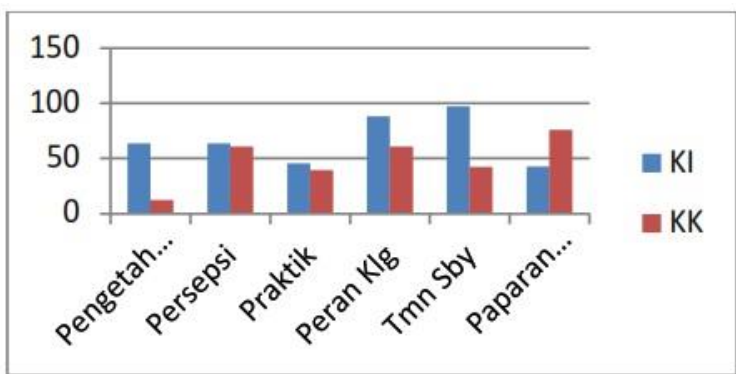

*Uji chi square $p<0.05$, pengetahuan $(p=0.004)$, persepsi $(p=0.107)$, praktik $(p=0.016)$, peran keluarga $p=0.001)$, pengaruh teman sebaya $(p=0.022)$ dan paparan media $(p=0.098)$

Hasil penelitian sesudah intervensi terhadap pengetahuan, persepi, praktik, peran keluarga, pengaruh teman sebaya dan paparan media sebelum diberikan intervensi baik pada kelompok intervensi dan kelompok kontrol didapatkan hasil $\mathrm{p}<0,05$, hal ini menunjukkan bahwa ada perbedaan yang bermakna terhadap pengetahuan, persepi praktik, peran keluarga, pengaruh teman sebaya dan paparan media sebelum diberikan intervensi baik pada kelompok intervensi dan kelompok control

Hal ini dikarenakan selain diberikan pendidikan kesehatan reproduksi, booklet diberikan kepada kelompok intervensi sedangkan kelompok kontrol tidak. dengan harapan kelompok intervensi dapat dipelajari saat dirumah.

Hasil penelitian sejalan dengan penelitian di santri pondok pesantren disemarang oleh Haning Khoirunisa (2015), bahwa ada perbedaan antara pengetahuan santri pondok pesantren intervensi dan kontrol tentang kesehatan reproduksi dengan $\mathrm{p}=0.001 \quad(\mathrm{p}<0.05)$ dimana mean intervensi 97,36 sedangkan kontrol 85,0615.

Sesuai juga dengan teori Notoadmodjo (2007) bahwa dalam waktu yang pendek (immediate impact) pendidikan kesehatan reproduksi dapat menghasilkan perubahan atau peningkatan pengetahuan, hal ini juga selaras dengan penelitian dari Tri Prapto Kurniawan yang menyebutkan bahwa pengetahuan remaja tentang kesehatan reproduksi terbanyak kategori sedang 55,4\% 16. Pengetahuan remaja mengenai kesehatan reproduksi merupakan perpaduan antara pengetahuan yang diperoleh dari mata pelajaran biologi disekolah dan pengetahuan lokal yang bersumber dari interaksi sehari- hari dalam kehidupan sosial.

Perbedaan pengetahuan, persepsi, praktik dan variabel counfounding sebelum intervensi pada kelompok intervensi dan kelompok kontrol Tabel 3. Perbedaan pengetahuan, persepsi, praktik dan variabel counfounding sebelum intervensi pada kelompok intervensi dan kelompok kontrol

\begin{tabular}{|c|c|c|c|c|}
\hline \multicolumn{2}{|c|}{ Variabel } & $\begin{array}{c}\text { Medi } \\
\text { an }\end{array}$ & SD & P-value \\
\hline \multicolumn{5}{|l|}{ Variabel } \\
\hline \multirow{2}{*}{$\begin{array}{l}\text { Pengetahu } \\
\text { an }\end{array}$} & K.Intervensi & 9.00 & 1.709 & $0.560^{\mathrm{a})_{* *}}$ \\
\hline & K.Kontrol & 9.00 & 1.275 & \\
\hline \multirow[t]{2}{*}{ Persepsi } & K.Intervensi & 9.00 & 1.938 & $0.077^{\mathrm{a})_{* *}}$ \\
\hline & K.Kontrol & 8.00 & 1.474 & \\
\hline \multirow[t]{2}{*}{ Praktik } & K.Intervensi & 12.00 & 3.163 & $0.067^{\mathrm{a})_{* *}}$ \\
\hline & K.Kontrol & 14.00 & 1.873 & \\
\hline \multirow[t]{2}{*}{$\begin{array}{l}\text { Peran } \\
\text { keluarga }\end{array}$} & K.Intervensi & 14.00 & 2.822 & $0.968^{\mathrm{a}}{ }_{* *}$ \\
\hline & K.Kontrol & 11.00 & 1.523 & \\
\hline \multirow{2}{*}{$\begin{array}{l}\text { Teman } \\
\text { sebaya }\end{array}$} & K.Intervensi & 8.00 & 3.133 & $0.178^{\mathrm{a})_{* *}}$ \\
\hline & K.Kontrol & 8.00 & 1.952 & \\
\hline \multirow[t]{2}{*}{$\begin{array}{l}\text { Paparan } \\
\text { media }\end{array}$} & K.Intervensi & 5.00 & 1,906 & $0.053^{\mathrm{a})_{* *}}$ \\
\hline & K.Kontrol & 9.00 & 1.819 & \\
\hline
\end{tabular}

valuep $<0.05 * *)$ Tidak sig $p>0.05$

Tabel 3 menunjukkan hasil uji statistik Mann Whitney didapatkan p-value untuk pengetahuan $\mathrm{p}=0.560$, persepsi $\mathrm{p}=0.077$, praktik $\mathrm{p}=0.067$, peran keluarga $\mathrm{p}=0.968$, peran teman sebaya $\mathrm{p}=0.178$, paparan media $\mathrm{p}=0.053$, dimana $\mathrm{p}>0.05$ yang menunjukkan tidak ada perbedaan pengetahuan, persepsi, praktik dan variabel penganggu lainnya pada kelompok kontrol dan kelompok intervensi sebelum pemberian pendidikan kesehatan reproduksi. Hal ini dikarenakan kelompok kontrol dan kelompok intervensi belum mendapatkan pendidikan kesehatan reproduksi.

Maka dengan hasil tersebut juga untuk variabel peran keluarga, teman sebaya dan paparan media tidak menjalani pengujian selanjutnya, dikarenakan mempunyai hasil yang sama pada awal penelitian dan masuk ke dalam variabel penganggu.

Pengetahuan sebelum dan sesudah intervensi antara kelompok intervensi dan kelompok kontrol 
Tabel 4 Hasil uji beda pengetahuan sebelum dan setelah intervensi antara kelompok intervensi dan

\begin{tabular}{|c|c|c|c|c|}
\hline Variabel & $\begin{array}{c}\text { Median } \\
\text { Sebelum } \\
\text { Interven } \\
\text { si } \pm \text { SD }\end{array}$ & $\begin{array}{c}\text { Median } \\
\text { Sebelum } \\
\text { Interven } \\
\text { si } \pm \text { SD }\end{array}$ & $\begin{array}{c}\text { Median } \\
\text { Sesudah } \\
\text { Interven } \\
\text { si } \pm \text { SD }\end{array}$ & p-value \\
\hline Kelompok & $9.00 \pm$ & $10.00 \pm$ & $\begin{array}{c}1 \pm \\
0360\end{array}$ & $0.026^{\mathrm{b})}{ }_{*}$ \\
\hline $\begin{array}{l}\text { Intervensi } \\
\text { Kelompok } \\
\text { Kontrol }\end{array}$ & $\begin{array}{l}1.709 \\
9.00 \pm \\
1.275\end{array}$ & $\begin{array}{l}1.347 \\
8.00 \pm \\
1.786\end{array}$ & $\begin{array}{l}0.362 \\
-1 \pm- \\
0,511\end{array}$ & $0.001^{\mathrm{b})_{*}}$ \\
\hline $\begin{array}{l}\left.{ }^{a}\right) \text { Mann } \mathrm{V} \\
\text { c) } \\
\text { chi squa } \\
\text { sig p }>0.0\end{array}$ & $\begin{array}{l}\text { itney } \\
*) \text { sig }\end{array}$ & $\begin{array}{l}\text { Nilcox } \\
\text {-value }\end{array}$ & $\begin{array}{l}\text { signe } \\
0.05\end{array}$ & $\begin{array}{l}\text { rank tes } \\
* \text { )Tidak }\end{array}$ \\
\hline
\end{tabular}

Tabel 4 menunjukkan rerata skor pengetahuan remaja tentang kesehatan reproduksi antara sebelum dan sesudah pemberian pendidikan kesehatan reproduksi dengan menggunakan Wilcoxon test diperoleh $\mathrm{p}=0.026 \quad(\mathrm{p}<0.05)$ pada kelompok intervensi dan $\mathrm{p}=0.001(\mathrm{p}<0.05)$ pada kelompok kontrol, sehingga dapat diartikan bahwa ada perbedaan pengetahuan remaja mengenai kesehatan reproduksi sebelum dan sesudah pemberian pendidikan kesehatan reproduksi antara kelompok intervensi dan kelompok kontrol. Perbedaan tersebut menunjukkan adanya peningkatan pengetahuan sesudah diberikan pendidikan kesehatan reproduksi pada kelompok intervensi dan pada kelompok kontrol tidak mengalami perubahan pengetahuan

Persepsi sebelum dan sesudah intervensi antara kelompok intervensi dan kelompok control

Tabel 5 Hasil uji beda persepsi sebelumdan setelah

\begin{tabular}{lcccc}
\hline Variabel & $\begin{array}{c}\text { Median } \\
\text { Sebelum } \\
\text { Interven } \\
\text { si } \pm \text { SD }\end{array}$ & $\begin{array}{c}\text { Median } \\
\text { Sesudah } \\
\text { Interven } \\
\text { si } \pm \text { SD }\end{array}$ & $\begin{array}{c}\text { Median } \\
\text { Interven } \\
\text { si } \pm \text { SD }\end{array}$ & p-value \\
\hline Kelompok & $9.00 \pm$ & $10.00 \pm$ & $1 \pm$ & $0.001^{\text {b) }}{ }_{*}$ \\
Intervensi & 1.938 & 0.977 & 0.961 & \\
Kelompok & $8.00 \pm$ & $9.00 \pm$ & $-1 \pm$ & $0.001^{\text {b) }}$ \\
Kontrol & 1.474 & 0.810 & 0.664 & \\
\hline
\end{tabular}

intervensi antara kelompok intervensi dan control

Tabel 5 menunjukkan rerata skor persepsi remaja tentang cybersex antara sebelum dan sesudah pemberian pendidikan kesehatan reproduksi dengan menggunakan Wilcoxon test diperoleh $\mathrm{p}=0.001$ $(\mathrm{p}<0.05)$ pada kelompok intervensi dan $\mathrm{p}=0.001(\mathrm{p}<0.05)$ pada kelompok kontrol, sehingga dapat diartikan bahwa ada perbedaan persepsi remaja mengenai cybersex sebelum dan sesudah pemberian pendidikan Kesehatan reproduksi antara kelompok intervensi dan kelompok kontrol. Perbedaan tersebut menunjukkan adanya peningkatan persepsi sesudah diberikan pendidikan Kesehatan reproduksi pada kelompok intervensi, sedangkan pada kelompok kontrol tidak mengalami perubahan persepsi terkait dengan cybersex.

Praktik sebelum dan sesudah intervensi antara kelompok intervensi dan kelompok kontrol

Tabel 6 Hasil uji beda Praktik sebelum dan setelah intervensi antara kelompok intervensi dan kontrol

\begin{tabular}{|c|c|c|c|c|}
\hline Variabel & $\begin{array}{c}\text { Median } \\
\text { Sebelum } \\
\text { Interven } \\
\mathbf{s i} \pm \text { SD }\end{array}$ & $\begin{array}{c}\text { Median } \\
\text { Sesudah } \\
\text { Interven } \\
\text { si } \pm \text { SD }\end{array}$ & $\begin{array}{c}\Delta \\
\text { Median } \\
\text { Interven } \\
\text { si } \pm \text { SD }\end{array}$ & p-value \\
\hline Kelompok & $12.00 \pm$ & $7.00 \pm$ & $-5 \pm-$ & $0.001^{\mathrm{b})_{*}}$ \\
\hline $\begin{array}{l}\text { Intervensi } \\
\text { Kelompok }\end{array}$ & $\begin{array}{c}3.163 \\
14.00 \pm \\
1873\end{array}$ & $\begin{array}{c}4.053 \\
11.00 \pm \\
2.587\end{array}$ & $\begin{array}{l}0.89 \\
3 \pm-\end{array}$ & $0.004^{\mathrm{b})_{*}}$ \\
\hline$\frac{\text { Kontrol }}{\text { Mann V }}$ & $\frac{1.873}{\text { itney }}$ & $\frac{2.587}{2.11}$ & $\frac{0714}{\text { signec }}$ & \\
\hline
\end{tabular}

Tabel 6 menunjukkan rerata skor praktik remaja terkait cybersex antara sebelum dan sesudah pemberian pendidikan kesehatan reproduksi dengan menggunakan Wilcoxon test diperoleh $\mathrm{p}=0.001$ $(\mathrm{p}<0.05)$ pada kelompok intervensi dan $\mathrm{p}=0.004$ $(\mathrm{p}<0.05)$ pada kelompok kontrol, sehingga dapat diartikan bahwa ada perbedaan praktik remaja terkait cybersex sebelum dan sesudah pemberian pendidikan kesehatan reproduksi antara kelompok intervensi dan kelompok kontrol. Perbedaan tersebut menunjukkan adanya peningkatan secara negatif praktik cybersex sesudah diberikan pendidikan kesehatan reproduksi pada kelompok kontrol, sedangkan pada kelompok intervensi memiliki praktik yang cenderung menurun secara positif setelah diberikan pendidikan kesehatan reproduksi.

Perbedaan pengetahuan, persepsi dan praktik dan variabel counfounding sesudah intervensi pada kelompok intervensi dan kelompok kontrol Tabel 7 Perbedaan pengetahuan, persepsi dan praktik dan variabel counfounding sesudah intervensi pada kelompok intervensi dan kelompok kontrol

\begin{tabular}{lcccc}
\hline \multicolumn{2}{c}{ Variabel } & Median & SD & P-value \\
\hline $\begin{array}{l}\text { Variabel } \\
\text { Pengeta } \\
\text { huan }\end{array}$ & K. Intervensi & 10.00 & 1.347 & $0.001^{\mathrm{a})}$ \\
& K. Kontrol & 8.00 & 1.786 & \\
Persepsi & K. Intervensi & 10.00 & 0.489 & $0.042^{\mathrm{a})}$ \\
& K. Kontrol & 9.00 & 0.549 & \\
Praktik & K. Intervensi & 7.00 & 4.053 & $0.001^{\mathrm{a})}$ \\
& K.Kontrol & 11.00 & 2.646 & \\
\hline
\end{tabular}

$\left.{ }^{a}\right)$ Mann Whitney ${ }^{\text {b) Wilcoxon signed rank test }}$ c) chi square *)sig p-value $\mathrm{p}<0.05 \quad * *)$ Tidak sig $\mathrm{p}>0.05$

Tabel 7 menunjukkan hasil uji statistic Mann Whitney didapatkan besar p-value untuk pengetahuan $0.001 \quad(p<0.05)$, persepsi 0.042 $(\mathrm{p}<0.05)$, praktik $0.001(\mathrm{p}<0.05)$, yang menunjukkan ada perbedaan pengetahuan, persepsi, praktik pada kelompok kontrol dan kelompok intervensi sesudah pemberian pendidikan kesehatan reproduksi

Perbedaan perubahan pengetahuan, persepsi dan praktik sebelum dan setelah pemberian pendidikan kesehatan reproduksi antara kelompok intervensi dan kelompok kontrol

Tabel 8 Hasil uji beda perubahan pengetahuan, persepsi dan praktik remaja terkait cybersex sebelum dan setelah intervensi antara kelompok intervensi dan kontrol 


\begin{tabular}{lccc}
\hline Variabel & $\begin{array}{c}\Delta \\
\text { Intervensi } \\
\pm \text { SD } \\
\text { kelompok } \\
\text { intervensi }\end{array}$ & $\begin{array}{c}\boldsymbol{\Delta} \\
\text { Intervensi } \\
\pm \text { SD } \\
\text { kelompok } \\
\text { kontrol }\end{array}$ & $\begin{array}{c}\boldsymbol{p} \text { - } \\
\text { value }\end{array}$ \\
\hline Pengetah & $1 \pm 0.362$ & $-1 \pm-0,511$ & $.157^{\mathrm{c})_{* *}}$ \\
uan & & $-1 \pm 0.664$ & $\left..157^{\mathrm{c}}\right)_{* *}$ \\
Persepsi & $1 \pm 0.961$ & $\left.-157^{\mathrm{c}}\right)_{* *}$ \\
Praktik & $-5 \pm-0.89$ & $3 \pm-0714$ & .15 \\
\hline
\end{tabular}

Tabel 8 menunjukkan rerata skor pengetahuan, persepsi dan praktik remaja tentang kesehatan reproduksi antara sebelum dan sesudah pemberian pendidikan Kesehatan reproduksi dengan menggunakan Chi square diperoleh $\mathrm{p}=0.157$ $(\mathrm{p}<0.05)$ pada kelompok intervensi, sehingga dapat diartikan bahwa tidak ada perbedaan perubahan pengetahuan, persepsi dan praktik remaja mengenai kesehatan reproduksi sebelum dan sesudah pemberian pendidikan kesehatan reproduksi pada kelompok intervensi. Perbedaan perubahan tersebut menunjukkan tidak adanya perubahan pengetahuan, persepsi dan praktik sesudah diberikan Pendidikan kesehatan reproduksi pada kelompok intervensi.

Pemberian kesehatan reproduksi merupakan stimulus yang diperoleh oleh subyek, dalam hal ini menjelaskan bahwa persepsi seseorang dapat berubah ketika subyek menerima stimulus tersebut berupa informasi maka proses persepsi dimulai, tergantung dari penerimaan oleh subyek tersebut. Jika seseorang menerima informasi dalam bentuk positif maka persepsi yang diterima akan positif, namun jika informasi yang diterima di interpretasi negative maka persepsi yang muncul juga akan negative. ${ }^{17}$

Persepsi remaja yang meyakini bahwa dirinya memimiliki resiko yang lebih rendah terkait dengan perilaku seksual semakin mendorong remaja memenuhi kebutuhan seksual. ${ }^{18}$

Dalam peneilitian ini menjelaskan bahwa pemberian pendidikan Kesehatan reproduksi memberikan pengaruh yang positif baik terhadap kelompok kontrol dan kelompok intervensi, walaupun hasil pada kelompok kontrol jauh lebih tinggi $(100 \%)$ daripada kelompok intervensi (67\%), hal ini dapat diasumsikan bahwa para kelompok kontrol telah memiliki persepsi yang positif terhadap kesehatan reproduksi walaupun tanpa adanya pengaruh dari factor eksternal yaitu pemberian booklet. Hal ini dibuktikan dengan adanya penelitian oleh I Wayan Rasmen Adikusuma (2007) bahwa persepsi yang berbeda mengenai seks akan menyebabkan sikap yang berbeda juga terhadap seks itu sendiri sehingga akan mempengaruhi perilaku seksualnya. ${ }^{19}$

Mengakses internet telah menjadi konsumsi rutin seluruh lapisan masyarakat, tidak hanya menggunakan komputer atau laptop saja namun internet juga dapat di akses melalui handphone, internet bukan hanya dipergunakan untuk berinteraksi dengan orang lain, namun juga dipergunakan sebagai sarana sosialisasi, membentuk hubungan yang lebih bertahan lama, bahkan malah berkembang secara nyata di dalam kehidupan sosial. Terbukannya akses infromasi memungkinkan setiap orang untuk mengakses macam informasi termasuk yang menyajikan adegan seksual secara implisit. kebiasaan pengguna media yang ada adalah kebiasaan menyuguhkan sajian - sajian yang terlalu dini ataupun tidak layak dikonsumsi bagi anak-anak dan remaja. ${ }^{20}$

Hipotesa L. Green menjelaskan bahwa antara pengetahuan, sikap dan perilaku memiliki korelasi positif, jika pengetahuan seseorang positif, maka sikap dan perilaku yang ditampilkan pun sama persis, hal ini dipertegas oleh penelitian yang dilakukan oleh Yustina (2006), diungkapkan bahwa sikap yang baik (positif) didukung pula oleh pengetahuan yang relative baik. ${ }^{21}$ Hurlock mengatakan bahwa pada kelompok remaja masih labil dan belum mampu mengontrol diri, ketika terangsang dengan sajian yang berbau erotis membuat remaja tidak mampu menahan dorongan seksualnya. ${ }^{22}$

Pornografi bagi remaja merupakan sesuatu yang baru dan sangat menarik perhatian, semakin menarik informasi media pornograsi semakin banyak pengulangan informasi seksualitas yang terjadi. ${ }^{22}$ Rangsangan yang kuat dari luar seperti film-film seks, sinetron, buku buku bacaan dan majalah bergambar seksi, godaan dan rangsangan dari kaum pria serta pengamatan secara langsung terhadap perbuatan seksual tidak hanya mengakibatkan memuncaknya

\section{SIMPULAN}

Tidak ada perbedaan pengetahuan $\mathrm{P}=0.560$ $(\mathrm{p}>0.05)$, persepsi $\mathrm{P}=0.077 \quad(\mathrm{p}>0.05)$, praktik $\mathrm{P}=0.067$ ( $\mathrm{p}>0.05)$ dan variabel penganggu lainnya sebelum pemberian pendidikan kesehatan reproduksi antara kelompok intervensi dan kelompok kontrol. Ada perbedaan pengetahuan sebelum dan setelah pemberian pendidikan kesehatan reproduksi pada kelompok intervensi $\mathrm{P}=0.026 \quad(\mathrm{p}<0.05)$ dan kelompok kontrol $\mathrm{P}=0.001(\mathrm{p}<0.05)$. Ada perbedaan persepsi sebelum dan setelah pemberian pendidikan kesehatan reproduksi pada kelompok intervensi $\mathrm{P}=0.001 \quad(\mathrm{p}<0.05)$ dan kelompok kontrol $\mathrm{P}=0.001$ $(\mathrm{p}<0.05)$. Ada perbedaan praktik sebelum dan setelah pemberian pendidikan kesehatan reproduksi pada kelompok intervensi $\mathrm{P}=0.004 \quad(\mathrm{p}<0.05)$ dan kelompok kontrol $\mathrm{P}=0.001 \quad(\mathrm{p}<0.05)$. Tidak Ada perbedaan perubahan pengetahuan sebelum dan setelah pemberian pendidikan kesehatan reproduksi antara kelompok intervensi dan kelompok kontrol $\mathrm{P}=0.157$ ( $\mathrm{p}>0.05)$. Tidak ada perbedaan perubahan persepsi remaja terkait cybersex sebelum dan setelah pemberian pendidikan kesehatan reproduksi antara kelompok intervensi dan kelompok kontrol $\mathrm{P}=0.157$ $(\mathrm{p}>0.05)$. Tidak ada perbedaan perubahan praktik 
remaja terkait cybersex sebelum dan setelah pemberian pendidikan kesehatan reproduksi antara kelompok intervensi dan kelompok kontrol $\mathrm{P}=0.157$ $(\mathrm{p}>0.05)$. Tidak ada perbedaan peran keluarga sebelum pemberian pendiidikan kesehatan reproduksi antara kelompok intervensi dan kelompok kontrol $p=0.968(p>0.05)$. Tidak ada perbedaan pengaruh teman sebaya sebelum pemberian pendiidikan kesehatan reproduksi antara kelompok intervensi dan kelompok kontrol $\mathrm{p}=0.178$ $(\mathrm{p}>0.05)$. Tidak ada perbedaan paparan media sebelum pemberian pendiidikan kesehatan reproduksi antara kelompok intervensi dan kelompok kontrol $\mathrm{p}=0.053(\mathrm{p}>0.05)$

Rekomendasi dari penelitian ini adalah perlu adanya pelatihan terhadap guru ataupun guru BK terhadap pengetahuan kesehatan reproduksi dan hubungannya dengan kegiatan cybersex terhadap remaja sekolah. Meningkatkan kegiatan yang positif baik diluar dan didalam sekolah. Meningkatkan sistem pengamanan smarthphone pribadi terhadap kegiatan cybersex dari media sosial. Meningkatkan pemahaman serta pengetahuan tentang bahaya dan dampak jangka panjang terhadap segi negatif dari kegiatan cybersex.

\section{DAFTAR PUSTAKA}

1. Kementerian Kesehatan Republik Indonesia. Laporan Triwulan Ketiga 2014 kasus HIVAIDS. Kementerian Kesehatan Republik Indonesia. jakarta; 2014

2. Kementerian Kesehatan Republik Indonesia. Laporan Triwulan Ketiga 2014 kasus HIVAIDS. Kementerian Kesehatan Republik Indonesia. jakarta; 2014

3. Dinas kesehatan Banyuwangi. Laporan Triwulan kedua 2014. Dinas Kesehatan Banyuwangi; 2014.

4. Ali, M., Asrori M. Psikologi Remaja Perkembangan Peserta Didik, Edisi Kedua. Jakarta : Bumi Aksara; 2005

5. Soetjiningsih. Tumbuh Kembang Remaja dan Permasalahannya. Jakarta : CV Sagung Seto; 2007

6. dr, Kresna, adhiatma. Cybersex Sebagai Fenomen Seksual Masa Kini. diperoleh 02 desember 2014, http://www.tanyadok. com/seksualita/cybersex-sebagai-fenomenaseksual-masa-kini,by,diunduh tanggal 26 november 2014; 2013

7. Sugihartono, dkk. Psikologi Pendidikan.Yogyakarta : UNY Press; 2007

8. Jalaludin, Rakhmat, Persepsi Dalam Proses Belajar Mengajar, Jakarta : Rajawali Pers; 2007

9. Notoatmodjo, S. Promosi Kesehatan dan Perilaku Kesehatan. Jakarta: Rineka Cipta: 2012

10. Santrock, J.W. Psikologi Perkembangan. edisi 11 Jilid I. Jakarta : erlangga, 2007
11. Kumalasari I dan Andhyantoro, Kesehatan Reproduksi (Untuk Mahasiswa Kebidanan dan Keperawatan), jakarta : salemba medika; 2012

12. Sugihartono, dkk. Psikologi Pendidikan.Yogyakarta : UNY Press; 2007

13. Notoatmodjo, S. Metode Penelitian Kesehatan, Edisi Revisi, Jakarta : Rineka Cipta; 2005

14. Departemen Kesehatan RI. Pedoman Penyusunan Kurikulum dan Modul Pelatihan Berorientasi Pembelajaran. Jakarta: Pusdiklat Kesehatan; 2003

15. Haning Khoirunisa, Zahro Shaluhiyah, Priyadi Nugraha Prabamurti. Dampak Pemberian Pendidikan Kesehatan Reproduksi terhadap Pengetahuan, Sikap dan Praktek Santri Pondok Pesantren di Semarang, Jurnal Kesehatan Masyarakat (e-Journal) April 2015 (ISSN : 2356- 3346), http://e-journals1.undip.ac.id/index.php/jkm, 2015; 3 (3)

16. Kurniawan, Tri P. Analisis Hubungan Factor Factor Yang Berpengaruh Pada Remaja Dengan Kecenderungan Remaja Melakukan Hubungan Seksual (Intercourse) Pranikah Di Indonesia (Tesis); 2007

17. Suryadi, C.,Dkk, Kesehatan Reproduksi Buku I Dan II. Jakarta : FKM UI; 2002

18. Santrock, J.W. Psikologi Perkembangan. edisi 11 Jilid I. Jakarta : erlangga, 2007

19. Adikusuma, I wayan Rasmen. Sikap Remaja Terhadap Seks Bebas Di Kota Negara : Perspektik Kajian Budaya (Disertasi). program pendidikan doctor (S3) kajian budaya universitas udayana, denpasar bali, 2007

20. Marlian, Juliana. Pengaruh Pendidikan Proteksi Media Pornografi Video dan Komik Terhadap Perilaku Seks Remajad di SMKN Jakarta, UNDIP, Semarang (Tesis); 2016

21. Green LW. Kreuter MW. Health Promotion Planning: An Educational And Environment Approach. California : Mayfield Publising Co. 2000

22. Hurlock E,. Psikologi Perkembangan : Suatu Pendekatan Sepanjang Rentang Kehidupan. Jakarta : Penerbit Erlangga; 2002 